\title{
UPAYA PERAWAT DALAM MEMUTUS RANTAI INFEKSI UNTUK KESELAMATAN PASIEN DI RUMAH SAKIT
}

\author{
Fanisa Nur Siregar \\ fanisanursiregar09@gmail.com
}

\begin{abstract}
ABSTRAK
Seperti yang kita ketahui saat ini angka perkembangan infeksi di rumah sakit semakin tinggi. Rantai infeksi yang terjadi di rumah sakit dapat mengganggu keselamatan pasien, dokter,perawat dan tenaga kesehatan lainnya. Rantai infeksi ini harus di putus agar tidak terjadi penularan kepada pasien lain, dokter, perawat dan tenaga kesehatan yang lain. Upaya dalam memutus rantai infeksi berupa pencegahan dan pengendalian juga sebagai tugas perawat dalam memberikan asuhan keperawatan. Adapun tindakan yang dapat memutus rantai infeksi di rumah sakit adalah mencuci tangan setiap sebelum dan sesudah melakukan tindakan kepada pasien, menggunakan alat-alat yang steril, menggunakan APD berupa masker dan Handscoon saat melakukan tindakan keperawatan yang langsung bersentuhan dengan pasien.
\end{abstract}

Kata kunci : infeksi, upaya perawat, keselamatan pasien

\section{LATAR BELAKANG}

Menurut Keputusan Menteri Kesehatan Republik Indonesia No. 340/MENKES/PER/III/2010 Rumah sakit adalah institusi pelayanan kesehatan yang menyelenggarakan pelayanan kesehatan perorangan secara paripurna yang menyediakan pelayanan rawat inap, rawat jalan dan gawat darurat. Rumah sakit juga merupakan sebuah institusi pemberi pelayanan kesehatan yang bersifat kompleks, yang terdiri dari berbagai profesi dan padat modal yang menyediakan pelayanaan kesehatan perorangan. Sebagai pemberi layanan kesehatan, rumah sakit perlu melaksanakan keselamatan dan kesehatan kerja bagi dokter, perawat, tenaga kesehatan serta pasiennya. Pelaksanaan keselamatan dan kesehatan kerja (K3) di rumah sakit merupakan suatu upaya dalam menciptakan tempat kerja yang aman, sehat, dan bebas dari pencemaran lingkungan. 
Kualitas dari sistem pelayanan kesehatan khususnya adalah pelayanan keperawatan di rumah sakit dapat diukur dari berbagai indikator- indikator, salah satunya melalui penilaian terhadap infeksi. Infeksi silang yang berasal dari rumah sakit dan fasilitas pelayanan kesehatan lainnya dinamakan healthcare associated infection/HAIs. Infeksi ini merupakan suatu masalah yang serius bagi kesehatan masyarakat khususnya di rumah sakit. Infeksi dapat mengganggu keselamatan pasien selama dirawat di rumah sakit. Infeksi bisa saja datang dari pasien sendiri, melalui kontak dengan tenaga kesehatan, maupun berasal dari alat-alat medis yang digunakan selama proses perawatan, serta berasal dari lingkungan. Di Indonesia sendiri infeksi masih menjadi isu perbincangan di setiap fasilitas pelayanan kesehatan. Dilihat dari sumbernya infeksi bisa berasal dari komunitas atau kelompok dan berasal dari lingkungan rumah sakit. Pelaksanaan Pencegahan dan Pengendalian Infeksi(PPI) di Fasilitas Pelayanan Kesehatan memiliki tujuan untuk melindungi dan menjaga keselamatan pasien, tenaga kesehatan, pengunjung lain yang menerima pelayanan kesehatan serta masyarakat dalam lingkungannya dengan cara memutus rantai penularan penyakit infeksi. Dalam menjalankan asuhan keperawatan, tentunya perawat memiiki peran dalam memutus rantai infeksi dan perawat juga dapat menurunkan angka perkembangan rantai infeksi yang terjadi di ruang rawat, ruang operasi dan ruang rawat darurat sebuah rumah sakit. Perawat merupakan orang yang sering kontak langsung dengan pasien. Untuk itu perlu dilaksanakannya upaya perawat dalam memberikan asuhan keperawatannya agar memutus rantai infeksi yang sering terjadi di rumah sakit. Di rumah sakit sendiri sudah ada

organisasi yang menanggulangi infeksi yang terjadi yaitu organisasi PPI (Pencegahan dan Pengendalian Infeksi).

\section{METODE}

Metode yang digunakan untuk mendapatkan informasi dalam pembuatan jurnal ini adalah menggunakan metode kepustakaan yaitu membaca dan menganalisa jurnal online, e-book, skripsi, tesis dan sumber lainnya yang tepat, sesuai dan berfokus kepada upaya memutus rantai infeksi. Dengan menggunakan 10 sumber jurnal maupun e-book dengan terbitan paling tua tahun 2012. 


\section{HASIL}

Rumah sakit adalah fasilitas yang menyelenggarakan kegiatan pelayanan kesehatan dan dapat melayai pendidikan dan penelitian kesehatan. Rumah sakit dapat menjadi sumber terjadinya infeksi pada pasien yang di sebut dengan Healtcare Associated Infection (HAIs). HAIs merupakan infeksi yang terjadi pada klien dan tenaga medis di rumah sakit yang terjadi saat dilakukannya perawatan dan selama bekerja pada fasilitas pelayanan kesehatan lainnya, dimana saat masuk tidak ada infeksi dan masa intubasi, termasuk infeksi dalam rumah sakit namun muncul setelah pasien pulang, serta infeksi pada pekerjaan petugas rumah sakit serta terhadap tenaga kesehatan terkait proses pelayanan kesehatan dan fasilitas pelayanan kesehatan Kualitas dari sistem pelayanan kesehatan khususnya adalah pelayanan keperawatan di rumah sakit dapat diukur dari berbagai indikator- indikator, salah satunya melalui penilaian terhadap infeksi. Infeksi silang yang berasal dari rumah sakit dan fasilitas pelayanan kesehatan lainnya dinamakan healthcare associated infection/HAIs. Keselamatan pasien telah menjadi isu global yang paling penting saat ini dimana sekarang banyak dilaporkan tuntutan pasien atas kasus medical error yang terjadi pada pasien. Keselamatan pasien adalah pasien bebas dari cedera yang tidak seharusnya terjadi atau bebas dari cedera yang potensial akan terjadi (penyakit, infeksi, cedera fisik/psikososial,cacat, kematian) terkait dengan pelayanan kesehatanRantai infeksi yang terdapat di rumah sakit dapat menganggu keselaatan pasien. Upaya yang dapat dilakukan perawat dalam memutus rantai infeksi di rumah sakit adalah dengan kepatuhan dalam mencuci tangan sebelum maupun sesudah melakukan tindakan asuhan keperawatan kepada pasien. Kepatuhan perawat dalam menggunakan APD (alat pelindung diri) seperti masker dan sarung tangan saat melakukan tindakan langsung ke pasien. Kepatuhan menggunakan APD (alat pelindung diri) sangat berpengaruh dalam proses pencegahan Healtcare Associated Infection (HAIs). Kepatuhan dalam mengunakan alat pelindung diri sangat penting bagi seorang perawat juga.

\section{PEMBAHASAN}

Penularan rantai infeksi sering terjadi di lingkungan pelayanan medis, yang sangat beresiko terpapar ke tenaga kesehatan, pasien, pengunjung dan karyawan. Infeksi adalah suatu keadaan dimana ditemukan adanya agen infeksi (organisme) di dalam tubuh, dimana terdapat respon imun, tetapi tidak disertai gejala klinik. Rumah sakit merupakan sumber penularan rantai infeksi yang sangat besar. Dimana di rumah sakit terdapat berbagai macam orang dan berbagai 
jenis penyakit pula. Perawat merupakan tenaga kesehatan yang bersentuhan langsung dengan pasien dan dapat menjadi media penularan rantai infeksi baik bagi perawat sendiri maupun pasiennya. Perawat dapat mencegah terjadinya infeksi dengan cara memutuskan rantai penularan infeksi yang bisa terjadi.

Dalam memberikan pelayanan keperawatan, terinfeksi merupakan masalah yang sangat serius sehingga membutuhkan perhatian yang sangat besar dalam penatalaksanaannya. Prinsip umum yang harus diperhatikan adalah melindungi agar pasien tidak terinfeksi, pasien yang sudah terinfeksi tidak tertular oleh mikroorganisme yang lain, pasien yang sudah terinfeksi tidak menjadi sumber penularan bagi pasien yang lain, dan menjaga infeksi agar tidak berkembang dan menjadi lebih berbahaya. Dan juga menjaga diri sendiri agar tidak tertular infeksi yang berasal dari pasien maupun tenaga kesehatan yang lain. Pasien dalam masa perawatan kesehatan di rumah sakit sangat berisiko terkena infeksi karena daya tahan tubuh yang lemah, meningkatnya paparan terhadap jumlah dan jenis penyakit yang disebabkan oleh mikroorganisme. Infeksi silang yang berasal dari rumah sakit dan fasilitas pelayanan kesehatan lainnya dinamakan healthcare associated infection/HAIs. Healthcare Associated Infections (HAIs) merupakan infeksi yang didapat saat pasien dirawat di rumah sakit dan setelah pasien dirawat lebih dari 48 jam menerima pelayanan kesehatan. HAIs juga merupakan infeksi yang di dapatkan pasien ketika menerima pengobatan untuk kondisi medis ataupun bedah. Faktor -faktor yang memiliki peluang untuk terjadinya infeksi nosokomial (HAIs) yaitu:

a. Faktor dari diri penderita, seperti faktor usia, jenis kelamin, kondisi umum penderita, dan riwayat penyakitnya.

b. Faktor keperawatan, kondisi ini berkaitan dengan lamanya pasien dirawat selama di rumah sakit, menurunnya asuhan keperawatan yang diberikan, dan ruangan rawat inap yang padat.

c. Faktor mikroba patogen, seperti tingkat kemampuan invasi dan merusak jaringan, lamanya pemaparan antara sumber penularan dengan penderita.

Beberapa tindakan umum untuk mencegah penularan infeksi yaitu : 
1. Aseptik yaitu suatu tindakan untuk mencegah masuknya mikroorganisme kedalam tubuh yang mungkin akan mengakibatkan infeksi. Tujuannya untuk mengurangi atau menghilangkan sejumlah mikroorganisme yang akan masuk.

2. Antiseptik yaitu cara pencegahan infeksi dengan membunuh atau menghambat pertumbuhan mikroorganisme pada kulit dan jaringan tubuh.

3. Dekontaminasi merupakan langkah penting dalam penanganan peralatan, perlengkapan, sarung tangan, dan semua benda yang terkontaminasi oleh cairan ataupun darah pasien. Contohnya adalah alat-alat kesehatan, dan sarung tangan.

4. Pencucian yaitu tindakan menghilangkan semua kotoran yang kasat mata seperti darah, cairan tubuh, atau setiap benda asing seperti debu dengan sabun atau diterjen, air dan sikat. Tujuan dari pencucian untuk membantu menurunkan mikroorganisme yang berada di permukaan benda.

5. Sterilisasi yaitu tindakan menghilangkan semua mikroorganisme.

6. Desinfeksi merupakan tindakan menghilangkan sebagian besar mikroorganisme penyebab penyakit dari benda .

Dengan mempraktikkan cara pencegahan dan pengendalian infeksi yang baik dan benar, perawat dapat menghindarkan penyebaran infeksi yang berasal dari mikroorganisme terhadap pasien. Dengan meningkatnya rantai infeksi yang terjadi di rumah sakit, maka di perlukan peran perawat untuk memutus rantai penyebaran infeksi. Pencegahan dan pengendalian infeksi harus dilakukan oleh semua tenaga kesehatan seperti : perawat, dokter dan seluruh orang yang terlibat dalam perawatan pasien. Karena seluruh orang yang terlibat dalam memberikan perawatan krpada pasien juga termasuk salah satu komponen untuk pencegahan dan pengendalian infeksi. Hand hygiene menjadi salah satu langkah yang efektif untuk memutuskan rantai penyebaran infeksi, sehingga dapat memutus rantai infeksi. Berikut adalah upaya yang dapat dilakukan perawat dalam memutus rantai infeksi.

a. Kepatuhan perawat dalam mencuci tangan

Saat sebelum maupun sesudah melakukan tindakan asuhan keperawatan kepada pasien, perawat hendaknya mencuci tangan terlebih dahulu untuk mencegah dan memutus rantai infeksi. Cuci tangan merupakan suatu tindakan yang penting dalam pengendalian infeksi . Cuci tangan adalah suatu kegiatan dengan air mengalir ditambah dengan sabun atau sabun antiseptik yang 
bertujuan untuk membersihkan tangan dari kotoran atau mikroorganisme yang menempel dari tangan. Tujuan dari mencuci tangan merupakan suatu unsur pencegahan dalam penularan infeksi, karena penularan penyakit dapat terjadi ketika orang yang telah terinfeksi secara tidak sadar tidak mencuci tangan dengan benar kemudian langsung menyentuh makanan dan makanan tersebut dikonsumsinya maka mikroorganisme tersebut telah masuk kedalam tubuh. Mencuci tangan juga dapat menurunkan jumlah mikroorganisme pada tangan dan untuk mencegah penyebarannya ke area yang tidak terkontaminasi, seperti pasien, tenaga perawatan kesehatan dan peralatan. Indikasi mencuci tangan menurut World Health Organization dalam "My 5 Moments for Hand Hygiene", yaitu: sebelum menyentuh pasien, sebelum prosedur aseptik, setelah terekspore cairan tubuh, setelah menyentuh pasien, setelah menyentuh benda-benda di sekeliling pasien.

b. Kepatuhan menggunakan APD (alat pelindung diri)

Kepatuhan menggunakan APD sangat berpengaruh dalam proses pencegahan Healtcare Associated Infection (HAIs). Kepatuhan dalam mengunakan alat pelindung diri sangat penting bagi seorang perawat. Alat Pelindung Diri (APD) adalah suatu alat yang mempunyai kemampuan untuk melindungi seseorang yang fungsinya mengisolasi sebagian atau seluruh tubuh dari potensi bahaya di tempat kerja. Alat pelindung diri merupakan salah satu peralatan yang digunakan oleh tenaga kesehatan untuk mencegah terjadinya infeksi nosocomial. Pemakaian alat pelindung diri dalam kegiatan sehari hari lebih banyak berfungsi untuk pelindung pasien dibanding untuk pelindung perawat. Tujuan penggunaan alat pelindung diri adalah untuk melindungi kulit dan selaput lendir perawat dari pajanan semua cairan tubuh dari kontak langsung dengan pasien. Alat Pelindung diri meliputi sarung tangan, masker dan pelindung mata, topi, gaun dan apron. Salah satu alat pelindung diri yang digunakan untuk mencegah kontaminasi antara perawat dengan pasien saat melakukan tindakan adalah pemakaian sarung tangan dan masker. Faktor-faktor penting yang harus diperhatikan dalam penggunaan APD yaitu :

1) Menggunakan APD sebelum kontak dengan pasien

2) Mengguanakan dengan hati-hati jangan menyebarkan kontaminasi

3) Melepas dan membuang APD secara hati-hati ke tempat limbah infeksius yang telah tersedia 
4) Segera membersihkan tangan sesuai dengan langkah-langkah pada pedoman membersihkan tangan.

Oleh karena itu upaya perawat dalam memutus rantai infeksi di rumah sakit sangat penting. Dengan adanya kepatuhan perawat dalam pencegahan infeksi yang terjadi di rumah sakit mampu menurunkan perkembangan angka rantai infeksi yang terjadi di lingkungan rumah sakit.

\section{PENUTUP}

Tenaga kesehatan yang terlibat di rumah sakit diharapkan mampu memacu motivasi dari luar untuk meningkatkan kepatuhan dalam menggunakan alat pelindung diri terhadap perawat pelaksana dan lebih memperhatikan dalam hal standar operasional prosedur tentang penggunaan alat pelindung diri dan melakukan pemantauan lebih ketat lagi terhadap perawat yang rentan dengan resiko penularan dari pasien serta menambah fasilitas alat pelindung diri yang memadai dan berkecukupan. Perawat diharapkan mampu melakukan segala tindakan keperawatan dengan selalu patuh dan taat tidak hanya dalam menggunakan alat pelindung diri saja, namun juga bekerja sesuai dengan standar operasional rumah sakit.

\section{DAFTAR PUSTAKA}

Adhiwijaya, A. (2017). Pelaksanaan Pencegahan Dan Pengendalian Infeksi Dalam Peningkatan Mutu Pelayanan Di Rumah Sakit Umum Daerah Labuang Baji Makassar. Tesis. Fakultas Keperawatan Universitas Hasanuddin Makassar.

Arifianto. (2017). Kepatuhan Perawat dalam Menerapkan Sasaran Keselamatan Pasien pada Pengurangan Resiko Infeksi dengan Penggunaan Alat Pelindung Diri di Rs. Roemani Muhammadiyah Semarang. Tesis. Fakultas Kedokteran Universitas Diponegoro Semarang.

Dewi, F.,Handiyani, H., \& Kuntarti. (2016). Memutus Rantai Infeksi Melalui Fungsi Pengorganisasian Kepala Ruang Rawat . Jurnal Keperawatan Indonesia, Volume 19 No.2, 105-113.

Dhita, V., Pertiwiwati, E., \& Rizany, I. (2019). Motivasi Perawat Dengan Kepatuhan Menggunakan Alat Pelindung Diri . Nerspedia, 33-38 . 
Ernawati, E. (2014). Penerapan Hand Hygiene Perawat di Ruang Rawat Inap Rumah Sakit. Jurnal Kedokteran Brawijaya, Vol. 28.

Estri, B. A., \& dkk. (2019). Pengendalian Dan Pencegahan Infeksi (Ppi) . Yogyakarta: Universitas 'Aisyiyah Yogyakarta .

Fathi, A., \& Simamora , R. H. (2019, march). Investigating nurses' coping strategies in their workplace as an indicator of quality og nurses' life in Indonesia: a preliminary study. In IOP conference series. Earth and Environmental science (Vol. 248,No. 1, p. 012031. IOP Publishing.

Mumpuningtias, E. K., Aliftitah, S., \& Illiyini. (2017). Hubungan Tingkat Pengetahuan Dengan Perilaku Cuci Tangan Menggunakan Handrub Pada Keluarga Pasien Di Ruang Bedah Rsud Dr. H. Moh. Anwar Sumenep. Jurnal Ilmiah Keperawatan, Vol 12, No 2.

Putri, O. Z., \& dkk. (2017). Analisis Risiko Keselamatan Dan Kesehatan Kerja Pada Petugas Kesehatan Instalasi Gawat Darurat Rumah Sakit Akademik Ugm . JURNAL KESEHATAN, Vol. 10, No. 1, 1-12.

Sari, I. P. (2019). Efektifitas Kepatuhan Perawat Dengan Kejadian Infeksi Post Op Di Ruang Mawar Rsi Nashrul Ummah Lamongan . Medica Majapahit Vol 11. No. 2, 29-35.

Simamora, R. H. (2020). Learning of Patient Identification in Patient Safety Programs Through Clinical Preceptor Models. Medico Legal Update,20(3), 553-556.

Suhariono. (2019). pengelolaan keselamatan dan kesehatan kerja (K3) di rumah sakit. Jawa Timur: Uwais Inspirasi Indonesia. 